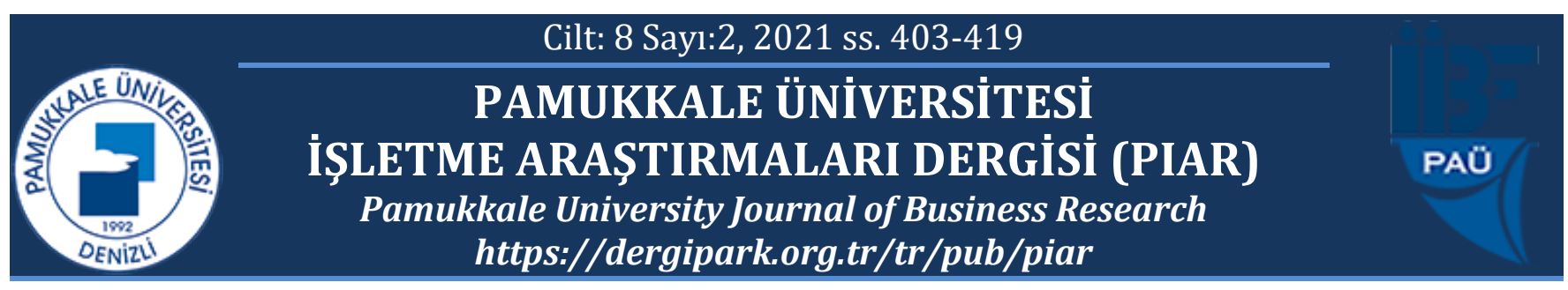

\title{
İşletme Sermayesi Yönetiminin Teknoloji Firmalarının Özsermaye Kârlılı̆̆ı Üzerine Etkisi
}

\author{
Effect of Working Capital Management on Equity Profitability of Technology \\ Firms
}

Umut UYAR ${ }^{1^{*}}$

Abdirahman RASHID ${ }^{2}$
Makale Geliș/Received: 11.07.2021

Öz

İşletme sermayesi yönetiminin finansal yönetim kararları açısından ciddi öneme sahip olduğundan son yillarda işletme sermayesi yönetiminin firma karlılı̆̆ına etkisi tartışılmakta olan konulardan biridir. Bu nedenle çalışmanın temel amaci, Borsa İstanbul'da teknoloji sektöründe faaliyet gösteren 13 firmanın, işletme sermayesi yönetiminin karllıklarına etkisini araştırmaktır. 2015-2020 yılları arasında firmalara ait çeyreklik finansal tablolar kullanularak toplam 312 gözlemden yararlanılmıştır. Çalışmada yöntem olarak panel veri analizi uygulanmıştır. Elde edilen sonuçlara göre, çalışmaya dahil olan 11 açıklayıcı değişkenden sadece beş tanesinin bağıml değişken olan öz sermaye karlılı̆̆ $\ddot{g}$ üerinde istatistiksel olarak anlamlı etkisi olduğu gözlenmiştir. Bu finansal oranlardan stok devir hızl, aktif devir hızı ve net işletme sermayesinin öz sermaye karlılığı üzerine etkisinin pozitif yönde; cari oran ve kaldıraç oranının ise negatif yönde olduğu tespit edilmiştir. Bu anlamda teknoloji firmalarmın likit seviyesini gereksiz arttırmalarn durumunda karlılklarm olumsuz etkilediği, aynı şekilde, toplam borç oranını arttıran firmaların risk düzeylerinin yükseldiği ve karlılıklarının düştü̈̆̈̈ tespit edilmiştir. Ayrıca stok devir hizı ve aktif devir hızı oranlarını arttıran firmalar, faaliyetlerini daha verimli gerçekleştirmekte ve sonuç olarak karlilıklarım artırabilmektedir. Son olarak da net işletme sermayesi yönetimine odaklanan teknoloji firmaları karlılıkların ciddi oranda yükseltebilmektedir.

Anahtar kelimeler: İşletme Sermayesi Yönetimi, Firma Karlılığı, Panel Veri Analizi

JEL kodlarn: G31, G32
Makale Kabul/Accepted: 23.10.2021

\begin{abstract}
Since working capital management is crucial from the point of view of financial management decisions, the impact of working capital management on firm profitability has been discussed in recent years. For this reason, the main aim of the study is to investigate the impact of working capital management on the profitability of 13 companies listed in the technology sector in Borsa Istanbul. In 2015-2020, a total of 312 observations were collected using the quarterly financial statements of firms. Panel data analysis was applied as a method in this study. According to the findings, only five of the 11 explanatory variables included in the study had a statistically significant effect on the dependent variable, which is return on equity. Among these financial ratios, it was found that stock turn over, asset turnover, and net working capital have a positive effect on return on equity, whereas the current ratio and leverage ratio have a negative effect. In this regard, it is found that if technology firms increase their liquid level unnecessarily, it negatively affects their profitability. The same is true, higher total debt ratio may lead to higher risk levels and lower profitability for firms. In addition, companies that increase stock and active turnover rates perform their activities more efficiently and increase their profitability. Finally, technology companies that concentrate on net working capital management can significantly increase their profitability.
\end{abstract}

Keywords: Working Capital Management, Profitability, Panel Data Analysis

JEL codes: G31, G32 


\section{GİRIŞ}

Son yıllarda, her sektörde iç ve dış rekabetin yükselmesi ve küresel ekonomik krizler nedeniyle işletme sermayesi hayati bir önemi taşır hale gelmiştir. İşletme sermayesi, kısa bir sürede paraya dönüşebilen ve bilanço aktifinde yer alan para, menkul kıymetler, alacaklar, stoklardan oluşmaktadır. İşletme sermayesi ve unsurları bir yıl içinde paraya dönüşebilme özelliği göstermektedir (Aydın vd, 2014: 163). İşletme sermayesi yönetimi açısından teoride iki temel soru bulunmaktadır: Birincisi işletme sermayesi tutarının ne olacağı; ikincisi ise işletme sermayesinin hangi kaynaklara ve nasıl finans edileceğidir (Brigham \& Ehrhardt, 2019: 642).

İşletme sermayesi, firmanın tam kapasite ile çalışabilmesi, faaliyetlerini karlı ve verimli bir şekilde sürdürebilmesi, iş hacmini genişletebilmesi, yükümlülüklerini karşılayamama riski ortadan kaldırması, kredi değerliliğini yükseltmesi, beklenmeyen olaylar ve zor durumlara düşme riski ortadan kaldırması için büyük bir önem taşımaktadır (Akgüç, 1982: 201). Bu doğrultuda finans yöneticisinin işletme sermayesi etkin bir şekilde yönetmesi gerekmektedir. Aksi durum, birçok sektörde firmaların iflas riski ile karşı karşıya kalabilmelerine sebep olmaktadir.

Finansman stratejisi açısından konu ele alındığında, likidite ile karlılık arasındaki ters yönlü ilişki dikkat çekmektedir. Likidite arttırıldığı durumlarda, işletmenin yükümlülüklerini zamanında yerine getirmeme riski azalacaktır ve dolayısıyla iflas olasılığından uzaklaşılacaktır. Aksi durumda, karlılık artırılmaya çalışıldığında, işletmenin likiditesi azalmakta ve yükümlülüklerini yerine getirmeme riski karşı karşıya kalabilmektedir. Kısa vadeli fonlama politikasını kullanılarak riski azalmanın yanı sıra karlılık artacaktır. Başka bir deyişle karlılıkla risk arasında doğrudan bir ilişki bulunmaktadır (Akgüç, 1982: 217). Söz konusu ilişki, her sektörde farklılık göstermektedir. Özellikle, son zamanların parlayan sektörü olan teknoloji sektöründe işletme sermayesi yönetimi, büyük önem arz etmektedir. Sabit yatırım maliyetinin yüksek olduğu teknoloji firmalarında, kısa vadeli varlıkların yönetimi, firmaların günlük işleyişleri ve yükümlülüklerini yerine getirebilmeleri açısından ciddi problemler oluşturabilmektedir. Likidite-karlılık dengesinin verimli şekilde oluşturulamaması, teknoloji firmalarının optimal bir karlılık seviyesine ulaşmasını engellemektedir.

Bu çalışmanın temel amacı, Borsa İstanbul teknoloji sektöründe yer alan 21 firmanın işletme sermayesi yönetimi ile karlılık durumlarının incelenmesidir. Bu amaç doğrultusunda 20152020 yılları arasındaki çeyreklik finansal tablo bilgileri, panel veri analizi ile araştırılmıştır. Önemi hali hazırda açıklanmış olan işletme sermayesinin teknoloji firmaları açısından ele alınması, literatüre güncel bir konunun dahil edilmesini sağlamaktadır. Teknolojik gelişmeler, yatırımcların teknoloji firmalarına daha fazla yatırım yapma arzusu taşımalarına neden olmaktadır. Çalışmanın araştırma kurgusunda, yatırımcılara, teknoloji firmalarının işletme sermayesi yönetimi açısından bilgi sağlanması hedeflenmektedir.

Çalışmanın sonraki bölümünde karlılıkla işletme sermayesi arasındaki ilişki ele alan literatür araştırması yer almaktadır. Üçüncü bölümde veri seti ve yöntemin açıklanmasını takiben, analiz bulguları üzerinde tartışılmaktadır. Son olarak sonuç ve önerilerin değerlendirilmesine yer verilmiştir. 


\section{LITERATÜR TARAMASI}

Son yıllarda firmaların performansı üzerine işletme sermayesi yönetimin etkisi ölçümlenmeye yönelik birçok araştırma yapılmıştır. İşletme sermeyesi ile firma performans arasında ilişki olup olmadığı belirlenmek amacıyla farklı araştırmacıların son yıllarda yaptığı çalışmalar aşağıda sıralanmaktadır.

Lazaridis ve Tryfonidis (2006) araştırmalarında işletme sermayesi (nakit, alacak ve borç) unsurlarıyla karlılık arasındaki ilişki belirlemeye çalışmışlardır. Bu çalışmada Atina Borsasında yer alan 131 işletmenin 2001-2004 dönemlerine ait verileri yararlanmıştır. Çalışmada brüt kar marjı bağımlı, nakit dönüş süresi ve bileşenleri bağımsız değişkenler olarak kullanılmıştır. Ayrıca firma büyüklüğü (doğal satışların logaritması) ve finansal borç oranı kontrol değişken olarak kullanılmıştır. Regresyon analizi yöntemiyle test edilen bu çalışmanın sonucuna göre firma karlılığı ile nakit dönüş süresi ve bileşenleri arasında negatif ve anlamlı bir ilişki olmanın yanı sıra karlılıkla firma büyüklügü pozitif bir ilişki karlılıkla kaldıraç oranı ise negatif bir ilişki olduğu kanısına varılmıştır.

Raheman ve Mohamed (2007) Karaçi Borsasında faaliyette bulunan 94 firmanın (1999-2004) arasındaki 6 yıllık verileri kullanarak yaptıkları çalışmada firma karlılığı üzerine çalışma sermayesi yönetiminin etkisi incelemişlerdir. Pearson korelasyonu ve regresyon analizi ile test edilen bu çalışmanın sonucuna göre çalışma sermayesi ölçüsü olarak nakit dönüşüm süresi ve bileşenleri, likidite oranları ve kaldıraç oranı ile karlılık arasında anlamlı ve negatif bir ilişki, firma büyüklüğü (satışların logaritması) ile de anlamlı ve pozitif bir ilişki olduğu sonucuna varılmıştır.

Nazir ve Afza (2009) Pakistan'da faaliyet gösteren firmaların 8 yıllık verileri derlenerek panel veri yöntemiyle agresif çalışma sermayesi yönetimi politikasının firmaların karlılığı üzerine etkisi araştırmışlardır. Çalışmanın sonucunda agresif çalışma sermayesi yönetimi ile karlılık ölçüsü olarak aktif karlılığı arasında negatif ve istatistiksel olarak anlamlı bir ilişki olduğu görülmüştür. Diğer taraftan, agresif çalışma sermayesi yönetimi ile firma değeri ölçüsü olarak Tobins'q arasındaki ilişki de pozitif ve istatistik açıdan anlamlı olduğu görülmüştür. Bunun anlamında firmaların işletme sermayesi finansmanın yükselmesiyle karlılıklarını artırabildiği şeklinde yorumlanmıştır.

Karaduman vd (2010) firmaların karlılığı ölçüsü olarak aktif karlılığı çalışma sermayesi yönetimi tarafından etkilenip etkilenmediği sonucuna ulaşmak için panel veri analizi ile kullanmışlardır. Çalışmada Borsa İstanbul'a kayıtlı olan 140 firmanın 2005-2008 yılları arasındaki dönemlerine ilişkin verileri kullanılarak yapılan panel veri analizi tahmini sonucunda çalışma sermayesi unsurlarının aktif karlılı̆̆ına etkisi olduğu söz konusudur. Araştırmada firma yöneticisinin stok devir süresi, alacak tahsilat süresi, borç ödeme süresi ve nakit dönüşs süresi düşürerek firma karlılığını artırabileceği söylenmiştir.

Akbulut (2011), çalışmasında işletme sermaye yönetiminin firmanın karılılığı üzerine etkisi olup olmadığına yönelik bir araştırma gerçekleştirilmiştir. 2000-2008 yıllarında kesintisiz bir şekilde faaliyetlerini sürdüren ve Borsa İstanbul'da faaliyet gösteren imalat sektöründeki 127 işletmenin yıllık verileri analiz edilmiştir. Çalışmada regresyon analizi yöntemi kullanılmıştır. Çalışmada işletme sermayesini ölçen nakit akış süresi, alacak tahsil süresi ve stok tahsil süresi ile firma karlılığını ölçen aktif karlılığı arasında istatiksel olarak anlamlı bir 
ilişki tespit edilememiştir. Bunun yanı sıra bağımsız değişken olarak araştırmaya dahil olan aktif büyüklüğü, borç oranı ve satış büyüme oranının firmaların aktif karlılığına istatistik olarak anlamlı ve pozitif yönde bir etkisi olduğu ortaya koyulmuştur.

Coşkun ve Kök (2011), İMKB' de kayıtlı olan 7 farklı sektörün 74 üretim firmasının 1991-2005 yılları arasındaki verilerini kullanarak çalışma sermayesi politikalarının firmaların karlılığı üzerine etkisini incelemişlerdir. Çalışmada nakit dönüş süresi ve unsurları (alacak devir süresi, stok devir süresi ve borç devir süresi) işletme sermayesi etkinliğinin göstergesi olarak kullanılmıştır. Dinamik panel veri yöntemi ile kullanılan bu çalışmanın sonucuna göre nakit dönüş süresi, alacak tahsil süresi ve stok devir süresi ile aktif karlılığı arasında ters yönlü bir ilişki tespit edilirken; borç devir süresiyle karlılık arasında pozitif yönlü bir ilişki olduğu sonucuna varılmıştır. Başka bir deyişle, firmaların nakit dönüş süresi ve unsurları alacak devir süresi ve stok devir süresi düşük tutarak karlılığı artırabildiği bulgusuna ulaşılmıştır.

Aygün (2012), 2000-2009 yılları arasındaki Borsa İstanbul'da işlem gören 107 imalat firması üzerine yaptığı çalışmada korelasyon ve regresyon analizi ile kullanmıştır. İşletme sermayesi yönetiminin karlılık üzerine etkisi incelenmiştir. Analiz sonuçlarına göre, çalışma sermayesi göstergesi olarak nakit dönüş süresi ve unsurlarının işletmenin aktif karlılığına istatistiksel açıdan anlamlı ve negatif etkilediği bulgusuna ulaşılmıştır.

Charitou vd (2012), Endonezya Borsası'nda yer alan imalat firmaları üzerinde yaptıkları araştırmada, işletme sermayesi yönetiminin firmaların karlılı̆̆ çıkarmışlardır. 1998-2010 dönemlerinde işletmelerin mali tablolardan hesaplanan verileri regresyon yöntemiyle analiz edilmiştir. Yapılan çalışmanın sonucuna göre nakit dönüş süresi ve firma büyüklüğü (toplam varlıkların logaritması) ile firma karlılığı ölçüsü olarak aktif karlılığı (ROA) arasında pozitif; kaldıraç oranı ile aktif karlılığı arasında negatif bir etki olduğu ortaya konulmuştur. Genel anlamda stok dönüş süresi ve alacak tahsil süresinin yükselmesiyle ve borçların düşürülmesiyle firmaların karlılıkları artırabileceği bulgularına ulaşılmıştır.

Vural vd (2012) BİST'e işlem gören 75 imalat firmasının 2002-2009 arasındaki dönemlerine ilişkin verilerini kullanarak, çalışma sermayesi yönetimi ile karlılık arasındaki ilişkiyi incelenmişlerdir. Dinamik panel veri analizi kullanılan çalışma sonucunda, firmaların alacak tahsilat süresi, nakit akış süresi ve kaldıraç oranı ile karlılık arasında negatif; firma değeri ölçüsü olarak Tobins'q ile nakit dönüş süresi arasında pozitif; kaldıraç oranı ila firma değeri negatif yönlü bir ilişki olduğu belirlenmiştir. Sonuç olarak firmaların alacak tahsilat süresi, nakit akış süresi ve borç oranı düşürmesiyle karlılıkları artırabileceği sonucuna ulaşılmıştır.

Arshad ve Yasir M. G (2013), araştırmalarında işletme sermayesi yönetiminin firma karlılık üzerine etkisi incelemişlerdir. Araştırma kapsamında Karachi Borsasında (KSE) faaliyette bulunan 21 firmanın 2004-2010 yılları arasındaki verileri kullanılmıştır. Regresyon analizi yöntemiyle kullanılan bu çalışmanın sonucunda cari oranı ve dönen varlıklar/toplam varlıklar oranı ile firma karlılığı ölçüsü olarak aktif karlılığ edilmiştir. Asit-testi oranı ile aktif karlılığı arasında ise negatif bir ilişki olduğu belirtilmiştir. Ayrıca çalışmaya dahil olan diğer değişkenler ile aktif karlılığı arasında anlamlı bir ilişki olmadığ 1 ifade edilmiştir. 
Altan ve Şekeroğlu (2013), İMKB' de işlem gören 16 firmanın 2003-2012 dönemleri arasındaki verilerini kullanarak, işletme sermayesi finansman stratejileri ile karlılık arasındaki ilişkiyi incelemişlerdir. Basit regresyon analizi kullanılan araştırmada, atılgan finansman politikasını izleyen firmaların en yüksek aktif karlılığı elde ettiği, ikinci sırada dengeli finansman politikasını, son olarak ise muhafazakar finansman stratejisini izleyen firmaların yer aldığı sunucuna ulaşılmıştır.

Ponsian (2014), Tanzanya'da Darüsselam Borsasında kayıtlı olan 6 imalat firmasının 20022012 arasındaki yıllık finansal tablolardan yararlanarak çalışma sermayesi yönetiminin karlılık üzerindeki etkisi ortaya koymuşlardır. İşletme sermayesi yönetiminin karlılık üzerine etkisi ölçemeye yönelik pearson korelasyon ve regresyon analizi kullanılmıştır. Yapılan analizinde stok dönüş süresi ve alacak tahsil süresini azaltan işletmelerin daha yüksek karlılık elde edebileceği; borç ödeme süresi ve nakit akış süresi artıran işletmelerin karlılıklarının artacağı ifade edilmiştir. Diğer bir deyişle, stok dönüş süresi ve alacak tahsil süresi ile karlılık olumsuz, borç ödeme süresi ve nakit akış süresi olumlu yönde olduğu sonucuna ulaşılmıştır. Ayrıca likidite ölçütü olarak cari oranı ve kaldıraç oranı artıkça firmanın karlılığı artacağı, satış büyüme oranı azalırsa firmanın karlılığı artacağ varılmıştır.

Kendirli ve Konak (2014), Borsa İstanbul'da Gida ve İçecek Endeksinde işlem gören 18 şirketin 2008-2012 dönemlerine ilişkin verileri kullanılarak firma performans ile çalışma sermaye yönetimi arasında herhangi bir ilişki olup olmadığına yönelik araştırma yapmışlardır. Çalışmada firma performans ölçütü olarak aktif karlılık, özsermaye karlılığı ve Tobin's Q bağımlı değişken olarak; nakit dönüşüm süresi ve bileşenleri bağımsız değişkenler olarak; cari oran, satışların büyüklüğü (net satışların logaritması) ve borç oranı kontrol değişkenleri olarak kullanılmıştır. Uygulama bölümünde regresyon analizi yöntemi kullanılmıştır. Yapılan analizlerden elde edilen sonuçlara göre, alacak devir hızı, stok devir hızı, nakit dönüşüm hızı ve kaldıraç oranı ile aktif karlılığı (ROA) ve özsermaye karlılığ (ROE) arasında negatif yönlü ve anlamlı bir ilişki bulunmuştur. Diğer yandan, Tobin's Q'nun etkisiz olduğu tespit edilmiştir. Borç devir hızının firmaların aktif karlılığı üzerine negatif, özsermaye karlılığı üzerine pozitif yönde etkilediği sonucuna ulaşılmıştır. Bu anlamda stok devir süresi ve alacak tahsil süresi azalmasıyla firmaların karlılıkları artırabileceği şeklinde değerlendirilebilmektedir.

Mbawuni vd (2016), işletme sermayesi yönetimiyle karlılık arasındaki ilişki incelenmek suretiyle Gana firmaların 2008-2013 dönemleri arasındaki verilerinden faydalanmıştır. Panel veri tahminleri neticesinde nakit dönüşüm süresi, alacak ve stok devir süresinin aktif karlılık üzerine anlamlı bir etkisi olmadığı; borç ödeme süresinin aktif karlılık üzerine etkisi negatif ama güçlü olduğu tespit edilmiştir. Sonuç olarak borç ödeme süresi yükselmesiyle karlılığın artabileceği vurgulanmıştır.

2005-2014 yılları arasındaki verileri derleyerek, Borsa İstanbul'da faaliyette bulunan 110 firma üzerinde yaptığı çalışmada Öner (2016), firma karlılığına işletme sermaye yönetiminin etkisini incelemiştir. Panel veri yöntemi kullanılan analizler sonucunda, faaliyet karlılık oranı ile nakit dönüşüm süresi, alacak tahsilat süresi, stok tutma süresi ve kaldıraç oran arasında anlamlı ve negatif bir ilişki tespit edilmiştir. Diğer yandan, faaliyet karlılık oranı ile 
borç ödeme süresi, firma büyüklüğü (log toplam varlığı), satışlardaki büyüme oranı ve cari oran arasında anlamlı ve pozitif bir ilişki olduğu ortaya konulmuştur.

Helhel ve Karasakal (2017) araştırmalarında Borsa İstanbul'da işlem gören konaklama sektörünün işletme sermayesi yönetiminin karlılık performansı üzerine etkisi incelemişlerdir. Çalışmada 2005-2015 dönemlere ait 15 yıllık veri seti, panel veri analizi yöntemiyle analiz edilmiştir. Ayrıca, değişkenler arasında sahte ilişki olup olmadığına yönelik birim kök kullanılmıştır. Aktif karlılığı ve özsermaye karlılığını işletmenin karlılık performans ölçütü olarak kullanan analizlerde, net işletmeye sermayesi ve kaldıraç oranlarının işletmenin aktif ve özsermaye karlılılğına pozitif yönde etkilediği bulgusuna ulaşılmıştır. Alacak ve aktif devir hızının ise negatif yönde etkilediği, diğer bir bütün değişkenler istatistiksel olarak anlamsız olduğu ortaya konulmuştur.

Zengin vd (2017) BİST'e kayıtlı 15 firmanın 14 yıllık verilerini derlenerek firma karlılığının işletme sermayesini nasıl etkilediğini ortaya koymuşlardır. Panel veri analizi kullanılan araştırma sonucunda özsermaye karlılığı ile işletme sermayesi pozitif yönlü ve anlamlı, net kar marji ile işletme sermayesi yönetimi negatif yönlü ve anlamlı bir ilişki tespit edilirken; aktif karlılığının istatistiksel olarak anlamlı olmadığı tespit edilmiştir.

Kaynar (2018) işletme sermaye yönetimi ile firma karlılığı arasındaki ilişkiyi araştırmak için panel veri analizi kullanmıştır. Çalışmada Borsa İstanbul'da faaliyet gösteren ve lojistik sektöründe yer alan firmaların 2013-2017 dönemlerindeki verileri kullanılmıştır. Analizler sonucunda, stok devir hızı, alacak devir hızı ve kısa vadeli borç ödeme süresi ile aktif karlılığı ve özsermaye karlılığı arasında anlamlı bir ilişki olmadığ1 göze çarpmıştır. Ayrıca nakit oran, asit test oranı ve aktif devir hızı oranları ile aktif karlılığı (ROA) ve özkaynak karlılığı (ROE) arasında anlamlı bir ilişki olmadığı sonucuna varılmıştır.

Yenisu (2019), Borsa İstanbul'da kote olan 15 firmanın 2013-2017 yılları arasındaki mali tablolarını kullanarak, işletme sermaye yönetimiyle firmanın karlılığı arasında ilişki olup olmadığını araştırmıştır. Çalışmada aktif karlılığı ve özkaynak karlılığı bağımlı, çalışma sermayesi ölçütü olarak nakit dönüşüm süresi bağımsız değişken olarak kullanılmıştır. Borç oranı ve satışların büyüme hızı da kontrol değişkeni olarak kullanılmıştır. Analizler sonucunda aktif ve özkaynak karlılığı ile kaldıraç oranı ve nakit akışı hızının negatif ve anlamlı bir ilişki olduğu; ancak satış büyüme hızı ile karlılık arasında istatistiksel olarak anlamsız ilişki olduğu gözlenmiştir.

Nur ve Gökhan (2019), Borsa İstanbul'da yer alan imalat sektöründeki 32 firmanın 2010-2017 arasındaki dönemlerine ait mali tabalarından yararlanarak araştırma yapmışlardır. Araştırmada çalışma sermayesi yönetiminin firmaların karlılığı üzerine etkisini olup olmadığını incelemek amacıyla panel veri analizi yöntemi kullanılmıştır. Karlılık ölçütü olan aktif karlılığı bağımlı değişken, nakit dönüş süresi ve firma büyüklüğü (logaritmik toplam varlık) ise bağımsız değişken olarak kullanılmıştır. Panel veri analizinin bulgularına göre firmaların, büyüklüğü, nakit dönüş süresi ve stok devir süresini artırarak aktif karlılığını yükseltebildiği sonucuna ulaşılmıştır. Diğer yandan, borç oranı ile firmanın aktif karlılığ arasında anlamlı ve ters yönlü bir ilişki olduğu bulgusuna varılmıştır.

Dinçergök (2019), çalışma sermayesi yönetimiyle karlılık arasındaki ilişki incelemek amacıyla Borsa İstanbul'da işlem gören Kimya, Petrol, Kauçuk ve Plastik ürünleri 
sektöründe yer alan 25 firmanın mali tablolarından derlenen veri setini kullanmıştır. 20052016 yılları arasını kapsayan çalışmada, dinamik panel veri analizi yöntemi tercih edilmiştir. Analiz sonuçlarına göre, faaliyet karı ile alacak devir süresi firmanın karlılığıyla doğrusal olmayan bir ilişki içerisindedir. Stok devir süresi için ise ters yönde bir ilişki söz konusudur. Ayrıca faaliyet karlılığı ile alacak devir hızı arasında konkav bir ilişki olduğu; başka bir ifadeyle ticari borçların bir noktaya kadar karlılığı artabildiği ancak bu noktadan sonra karlılığa zarar verebildiği sonucuna varılmıştır.

Eskin ve Güvemli (2019), işletme sermaye yönetimiyle firmaların karlılığı arasındaki ilişki belirlemeye yönelik bir çalışma yapmışlardır. Bu çalışmada işletme sermayesi göstergesi olarak nakit dönüş süresi, firmaların karlılığı ölçüsü olarak aktif karlılık ve faaliyet karlılığ1 kullanılmıştır. Çalışmada BİST'de yer alan 33 finansal olmayan firmanın 2012-2016 arasındaki 5 yıllık mali tablolarından yararlanılarak veriler derlenmiştir. Araştırmaya dahil edilen firmalın 11 sektör olarak gruplanmıştır. İşletme sermaye yönetiminin karlılık üzerine etkisi incelenmek amacıyla korelasyon analizi ve regresyon analizi kullanılmıştır. Araştırmaya dahil edilen 8 adet değişkenin öncelikle sektörel bazda ortalamaları hesaplanarak teknoloji, metal ve taş ve toprak sektöründe yer alan firmaların en yüksek nakit dönüşüm süresine sahip oldukları ortaya konulmuştur. Elektrik, gaz ve su sektöründe yer alan firmaların ise en düşük nakit dönüşüm süresine sahip olduğu vurgulanmıştır. Yapılan analiz sonucuna göre finansal kaldıraçla faaliyet karlılığı, firma yaşıyla aktif karlılığı arasında pozitif ve istatistiksel olarak anlamlı bir ilişki bulunmuşken; diğer değişkenlerle firmanın karlılığı arasında herhangi bir ilişki olmadığı sunucuna ulaşılmıştır.

Türkmen ve Söylemez (2019), işletme sermayesi yönetiminin firmaların karlılığı üzerine etkisini araştırmışlardır. Çalışmada Borsa İstanbul'da kayıtlı olan ve 2010-2017 dönemlerinde faaliyetlerini süreklilik gösteren demir, çelik ve ana metal sanayi sektöründeki 14 firmanın mali tablolarından elde edilen veriler kullanılarak, çoklu regresyon yöntemi ile analiz edilmiştir. Elde edilen bulgulara göre asit-testi oranı, dönen varlık/toplam varlık oranın firmaların aktif karlılığı üzerine \%1 anlamlılık düzeyinde pozitif yönde etkilediği; alacak devir hızı ve işletme sermayesi devir hızının da \%5 anlamlılık düzeyinde negatif yönde etkilediği; çalışmaya katılan diğer değişkenlerle aktif karlılığı herhangi bir ilişki olmadığı belirtilmiştir.

Karagözoğlu vd (2019) yaptığı çalışmada işletme sermayesi yönetiminin firmaların karlılık üzerine etkisini ölçmüşlerdir. Çalışmada Borsa İstanbul'da faaliyet gösteren 102 imalat firmasının 2005-2017 dönemlerine ilişkin verileri kullanılmıştır. Çalışmanın amacına göre panel veri analizi kullanılmıştır. Elde edilen sonuçlara göre, imalat firmaların bütünü bakımından çalışma sermayesi unsurlarının karlılık üzerine önemli bir etkisi olduğu şeklinde değerlendirilmiştir.

Korkmaz ve Yaman (2019)'ın, Türkiye'de turizm sektöründe yer alan 6 şirket üzerine panel veri analizi kullanarak yaptığı yaptıkları çalışmanın amacı, işletme sermayesi yönetiminin firma karlılığına etkisi ölçmektir. Dört model kullanılarak analiz edilen ilişkiler sonucunda, nakit dönüşüm süresi, stok devir süresi ve alacak tahsil süresinin faaliyet karlılığı üzerinde istatistiksel olarak anlamlı ve negatif yönde etkisi olduğu belirlenmiştir. Borç ödeme süresi, cari oranı ve satışlardaki büyüme oranının ise faaliyet karlılığı üzerinde anlamlı ve pozitif 
yönde etkisi olduğu gözlenmiştir. Ayrıca çalışmaya dahil olan kaldıraç oranı ile karlılık arasında herhangi bir ilişki olmadığ 1 da belirtilmiştir.

Çankaya (2020) araştırmasında, çalışma sermayesi yönetimi ile karlılık arasındaki ilişkiye odaklanmıştır. Analizlerde çoklu doğrusal regresyon analizi kullanan yazar, BİST'e kayıtlı sağlık sektöründe yer alan şirketlerin 2016-2019 arasındaki 4 yıllık verilerini araştırmaya dahil etmiştir. Analizler sonucunda borç ödeme süresi, aktif büyüklüğü, borç oranı ve stok tutma süresinin karlılık göstergesi olarak aktif karlılığı etkilediği, diğer değişkenlerin aktif karlılı̆̆

Literatürde yer alan çalışmalar incelendiğinde genel bir yorum yapılacak olursa; işletme sermayesi yönetimi ile karlılık değişkenleri arasındaki ilişkiler üç temel grupta toplanabilmektedir. Bazı araştırmalar karlılık değişkeni ile işletme sermayesi değişkeni arasında pozitif ilişki tespit ederken (Lazaridis ve Tryfonidis 2006; Nazir ve Afza 2009; Charitou vd 2012; Helhel ve Karasakal 2017; Zengin vd 2017; Nur ve Gökhan 2019; Karagözoğlu vd 2019; Çankaya 2020); bir başka grup ilişkinin negatif yönlü olduğu bulgusuna ulaşmıştır (Raheman ve Mohamed 2007; Karaduman vd 2010; Coşkun ve Kök 2011; Aygün 2012; Vural vd 2012; Ponsian 2014; Kendirli ve Konak 2014; Öner 2016; Yenisu 2019; Dinçergök 2019; Türkmen ve Söylemez 2019; Korkmaz ve Yaman 2019). Diğer yandan, bir takım araştırma sonuçlarına göre karlılık değişkeni ile işletme sermayesi değişkeni arasında istatistiksel olarak anlamlı bir ilişki saptanamamıştır (Akbulut 2011; Mbawuni vd 2016; Kaynar 2018; Eskin ve Güvemli 2019). Literatür incelemesi sonucunda, karlılık ile işletme sermayesi yönetimi arasındaki ilişkinin, araştırma örneklemine ve dönemine göre farklılık arz edebildiği; genel geçer bir modele ulaşmanın mümkün olmadığı gözlenmiştir.

\section{VERI SETI VE MODEL}

İşletme sermayesi yönetiminin karlılık üzerine etkisi araştırmak amacıyla Borsa İstanbul'da işlem gören ve 2015-2020 arasındaki dönemlerde faaliyetleri kesintisiz bir şekilde devam eden teknoloji sektöründeki 13 firmanın verilerinden faydalanılmıştır. Hali hazırda 19 firmanın faaliyette bulunduğu Borsa İstanbul teknoloji sektöründe, 5 firma ilgili dönemler aralığında faaliyetlerinin kesintisiz olmaması sebebiyle çalışmaya dahil edilememiştir. Veri seti Bloomberg Professional Terminal programından elde edilmiştir ve 2015 birinci çeyrekten 2020 dördüncü çeyrek arasındaki dönemleri kapsamaktadır.

Çalışmada kullanılan bağımlı ve bağımsız değişkenler Tablo 1'de gösterilmiştir. Firmaların karlılık performansı ve işletme sermayesi yönetimi ölçülmeye yönelik seçilen değişkenler ve uygulanan yöntem konusunda literatürden yararlanılmıştır (Helhel ve Karasakal, 2017). Çalışma sermayesi yönetiminin firmaların kârlılıkları üzerine olan etkisini belirlemek amacıyla firma karlılığı ölçüsü olarak aktif karlılığı oransal değişkeni ile işletme sermayesi yönetimi arasında anlamlı bir ilişkinin olup olmadığı araştırılmıştır. 
Tablo 1. Bağımlı ve Bağımsız değişkenler

\begin{tabular}{|c|c|c|}
\hline \multicolumn{3}{|l|}{ Bağımlı Değişken } \\
\hline Özsermaye karlılığ1 & ÖZK & $\frac{\text { Dönem net karl }}{\text { toplam aktifler }}$ \\
\hline \multicolumn{3}{|l|}{ Bağımsız Değişkenler } \\
\hline Asit-test oranı & AT & $\frac{\text { Dönen varlek - stoklar }}{\text { Kesa vadeli borclar }}$ \\
\hline Stok devir buzı oran & SDU & Satılan malın maliyeti \\
\hline 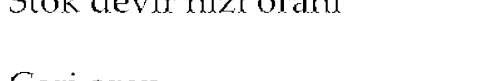 & SDTh & $\begin{array}{c}\text { Ortalama stoklar } \\
\text { Donen varllk }\end{array}$ \\
\hline Cari oran & $\mathrm{CO}$ & $\overline{\text { kisa vadeli borçlar }}$ \\
\hline Nakit oranı & $\mathrm{NO}$ & kasa + bankalar + m.kiymetler \\
\hline & & $\begin{array}{c}\text { kisa vadeli kaynaklar } \\
\text { net satıșlar }\end{array}$ \\
\hline Aktit devir hizı oranı & AKDH & $\begin{array}{c}\overline{\text { toplam aktifler }} \\
\text { toplam borçlar oranı }\end{array}$ \\
\hline Borç oranı & $\mathrm{BO}$ & $\begin{array}{c}\text { Özkaynaklar } \\
\text { dönen } v-k v b\end{array}$ \\
\hline Net işletme sermayesi oranı & NIS & $\begin{array}{c}\text { satışlar } \\
\text { net satıșlar }\end{array}$ \\
\hline İşletme sermayesi devir hıı1 & ISDH & $\overline{\text { ort.net ișletme sermeyesi }}$ \\
\hline $\begin{array}{l}\text { Kısa vadeli borç-toplam } \\
\text { borç oranı }\end{array}$ & KVBTB & $\frac{k v b}{\text { toplam borçlar }}$ \\
\hline Toplam borç oranı & TBO & $\frac{k v b+u v b}{\text { toplam aktifler }}$ \\
\hline
\end{tabular}

Kaynak: Helhel ve Karasakal (2017)

Tablo 2'de kullanılan bağımlı ve bağımsız değişkenlerine ait betimleyici istatistiklere yer verilmiştir.

Tablo 2. Betimleyici İstatistikler

\begin{tabular}{lllllll}
\hline \multirow{2}{*}{ Değişkenler } & $\begin{array}{l}\text { Gözlem } \\
\text { Sayıs }\end{array}$ & Ortalama & $\begin{array}{l}\text { Standart } \\
\text { Sapma }\end{array}$ & Medyan & Maksimum & Minimum \\
\hline OZK & 312 & 18.54547 & 14.69564 & 18.15275 & 65.88230 & -25.9803 \\
NO & 312 & 1.357399 & 3.729577 & 0.267250 & 23.07880 & 0.008200 \\
NIS & 312 & 2.626265 & 2.172480 & 1.934611 & 11.87784 & 0.504307 \\
KVBTB & 312 & 0.132592 & 0.118443 & 0.118893 & 0.504726 & 0.000000 \\
ISDH & 312 & 0.602371 & 0.383070 & 0.516905 & 1.982919 & 0.084190 \\
CO & 312 & 3.033867 & 4.099336 & 1.711500 & 28.33940 & 0.937500 \\
BO & 312 & 1.612241 & 1.385235 & 1.338806 & 7.037094 & 0.060261 \\
AT & 312 & 2.519725 & 4.161873 & 1.261900 & 27.96930 & 0.581800 \\
ADH & 312 & 1.669169 & 1.108680 & 1.156450 & 5.271000 & 0.390800 \\
TBO & 312 & 17.27201 & 14.44169 & 17.37450 & 67.59330 & 0.000000 \\
SDH & 312 & 22.28094 & 41.24240 & 10.00240 & 307.2004 & 1.833200 \\
\hline
\end{tabular}

Tabloda yer alan betimleyici istatistikleri incelendiğinde firmaların performans ölçüsü olarak kullanılan özkaynak karlılığı (ROE) ortalaması 18,5 iken; standart sapması yaklaşık \%14,7 olduğu görülmektedir. Çalışma sermayesi ölçüsü olarak kullanılan stok devir hızı ve işletme 
sermayesi devir hızı ortalamaları sırasıyla \%22,3 ve \%60,2 olduğu, aktif devir hızı ortalaması ise yaklaşık \%1,67 olduğu görülmektedir. Stok devir hızı ortalamasının ise 22,3 çıkmasına göre firmaların stoklarını çeyrekte yaklaşık 22,3 defa döndürdüğü, aktif varlıkları ise yaklaşı 1,67 kere yenilediği ifade etmektedir. Ayrıca likidite oranları göstergesi olarak kullanılan CO, AT ve $\mathrm{NO}$ ortalamaları sırasıyla 3,03, 2,51 ve 1,4 olarak gerçekleşmiştir. TBO ve $\mathrm{KVBTB}^{\prime}$ nın ortalamalarının ise 17,3 ve 0,13 olduğu görülmektedir.

Betimleyici istatistiklerin yapılmasının ardında açılayıcı değişkenler arasındaki ilişkilerin incelenmesine yönelik korelasyon matrisi oluşturulmuştur. Matris Tablo 3'te sunulmaktadır.

Tablo 3. Korelasyon matrisi

\begin{tabular}{|c|c|c|c|c|c|c|c|c|c|c|c|}
\hline & OZK & $\mathrm{NO}$ & NIS & KVBTB & ISDH & $\mathrm{CO}$ & BO & AT & $\mathrm{ADH}$ & ТВO & SDH \\
\hline OZK & 1,0000 & & & & & & & & & & \\
\hline $\mathrm{NO}$ & 0,0238 & 1,0000 & & & & & & & & & \\
\hline NIS & 0,0164 & 0,7026 & 1,0000 & & & & & & & & \\
\hline KVBTB & $-0,1339$ & $-0,3357$ & $-0,4154$ & 1,0000 & & & & & & & \\
\hline ISDH & 0,0904 & $-0,3428$ & $-0,7015$ & 0,5449 & 1,0000 & & & & & & \\
\hline $\mathrm{CO}$ & 0,0117 & 0,9820 & 0,6843 & $-0,3583$ & $-0,3401$ & 1,0000 & & & & & \\
\hline $\mathrm{BO}$ & 0,0084 & $-0,3207$ & $-0,4206$ & 0,4860 & 0,5378 & $\begin{array}{l}- \\
0,3698\end{array}$ & 1,0000 & & & & \\
\hline AT & 0,0321 & 0,9880 & 0,6938 & $-0,3471$ & $-0,3403$ & 0,9952 & $-0,3491$ & 1,0000 & & & \\
\hline $\mathrm{ADH}$ & 0,0941 & $-0,3227$ & $-0,6092$ & 0,3092 & 0,7967 & $\begin{array}{l}- \\
0,3236\end{array}$ & 0,4673 & $-0,3224$ & 1,0000 & & \\
\hline TBO & $-0,0842$ & $-0,3567$ & $-0,3866$ & 0,6568 & 0,3444 & $\begin{array}{l}- \\
0,4229\end{array}$ & 0,3921 & $-0,3931$ & 0,2249 & 1,0000 & \\
\hline SDH & 0,1539 & 0,6645 & 0,5120 & $-0,2448$ & $-0,1975$ & 0,6096 & $-0,2295$ & 0,6352 & $-0,2065$ & 0,1941 & 1,0000 \\
\hline
\end{tabular}

Tablo 3'te yer alan korelasyon matrisi incelendiğinde, likidite oranları (NO, CO ve AT) arasında oldukça yüksek bir korelasyon olduğu görülmektedir. Bu değişkenlerin aynı modelde yer alması durumunda, çoklu doğrusal bağlılık problemi (multicollinearity) görülebilecektir.

Çalışma amacına uygun olarak analizlerde, literatürde sık kullanılan panel veri analizi yöntemi tercih edilmiştir. Panel veri analizi hem zaman serilerini hem de yatay kesit verileri bir araya getiren bir yöntemdir. Başka bir deyişle, birden fazla dönemi kapsayan ve kesit boyutunu içeren bir yöntem olduğu için daha detaylı incelemeye izin vermektedir. İşletme sermayesi yönetiminin firmaların karlılığına etkisini değerlendirmek için aşağıdaki eşitlik kullanılarak panel veri analizi uygulanmıştır.

$\ddot{O} Z K_{i t}=\beta_{0}+\beta_{1} A T_{i t}+\beta_{2} S D H_{i t}+\beta_{3} C O_{i t}+\beta_{4} N O_{i t}+\beta_{5} A K D H_{i t}+\beta_{6} B O_{i t}+\beta_{7} N \mathrm{I}_{i t}+\beta_{8} \mathrm{I} S D H_{i t}+$ $\beta_{9} K V B T B_{i t}+\beta_{10} T B O_{i t}+\varepsilon_{i t}$

Çalışmada model tahmini yapılmadan önce, birtakım panel veri analizi varsayımlarının sinanması gerekmektedir. Bu testler, yatay kesit bağımlılığı, panel birim kök sinaması, değişen varyans ve son olarak otokorelasyon testi sınamalarıdır (Uyar ve Sarak, 2020). 


\section{YÖNTEM VE BULGULAR}

Çalışmanın amacı doğrultusunda, panel veri analizi yapılmadan önce birtakım varsayımların sınanması gerekmektedir. Öncelikle, serilerde yatay kesit bağımlılığı ve birim kök problemlerinin olup olmadığı incelenmelidir. Modellerde yatay kesit bağımlılı̆̆ bulunması halinde, birinci nesil yerine ikinci nesil birim kök testlerinin kullanılması önerilmektedir (Uyar ve Sarak, 2020). Daha sonra, değişen varyans ve otokorelasyon testlerinin yapılması gerekmektedir. Değişen varyans ve/veya otokorelasyon sorunların bulunması durumunda ise tahminlerin sağlıklı yapılabilmesi için dirençli (robust) tahminci kullanilmalıdır.

Yatay kesit bağımlılığını incelmek için çalışmada Breusch-Pagan LM testi tercih edilmiştir. Breusch ve Pagan (1980), havuzlanmış en küçük kareler modelinin kalıntılarına dayanan bir Lagrange Multiplier (LM) testi geliştirmişlerdir. Test istatistiği 1 serbestlik dereceli dağılımına uyum sağlarken, tesadüfi birim etkilerin varyansının sifır olduğu, $H_{0}: \sigma_{u}^{2}=0 ; H_{1}: \sigma_{u}^{2} \neq c$ hipotezleri ile sinanmaktadır. Test istatistikleri Tablo 4 'de sunulmuştur.

Tablo 4. Breusch-Pagan LM yatay kesit bağımlılığı testi

\begin{tabular}{|c|c|}
\hline$\chi^{2}$ Değeri & Olasılık Değeri \\
\hline 89316,39 & $0,0000^{*}$ \\
\hline
\end{tabular}

Tablo 4'de yer alan Breusch-Pagan LM test sonucuna göre sıfır hipotezi \%1 istatistiksel anlamlılık düzeyinde reddedilmektedir. Bu durumda, modelde yatay kesit bağımlılığı bulunmamaktadir.

Yatay kesit bağımlılığı sınaması sonrasında serilerin durağanlığı birinci birim kök testlerinden Levin-Lin-Chu birim kök testi ile gerçekleştirilecektir. Levin, Lin ve Chu (2002) çalışmalarında, birim kök test istatistiklerindeki regresyon denkleminin farklı tanımlamaları altında asimptotik varyans ve ortalamalarının değiştiğini tespit etmiştir. Panelde yer alan tüm birimlerin birinci dereceden kısmi otokorelasyona sahip olduğunu varsayılmaktadır ve buna göre üç farklı model önerilmektedir. Modeller sabit parametresiz (Eşitlik 2), sabit parametreli (Eşitlik 3) ve sabit parametreli ve trendli (Eşitlik 4) olarak oluşturulmaktadır.

$\Delta y_{i t}=\rho y_{i t-1}+u_{i t}$

$\Delta y_{i t}=\alpha_{0 i}+\rho y_{i t-1}+u_{i t}$

$\Delta y_{i t}=\alpha_{0 i}+\alpha_{1 i}+\rho y_{i t-1}+u_{i t}$

Levin-Lin-Chu birim kök testi sürecinde Eşitlik 2' de boş hipotez, $\overline{H_{n}: \rho=0}$ iken; alternatif hipotez ise $\overline{H_{n}: \rho<0}$ şeklindedir. Eşitlik 3 'te yer alan sabit parametreli modelde ise boş hipotez, $\overline{H_{n}: \rho=0}$ ve $\overline{\alpha_{n i}=C}$ iken; alternatif hipotez $\overline{H_{n}: \rho<0}$ ve $\overline{\alpha_{n i} \in R}$ olarak belirlenmiştir. Son olarak Eşitlik 4 'te yer alan sabit parametreli ve trendli modelde boş hipotez, $\overline{H_{n}: \rho=0}$ ve $\overline{\alpha_{1 i}=C}$ iken; alternatif hipotez $\sqrt{H_{n}: \rho<0}$ ve $\overline{\alpha_{1 i} \in R}$ olarak sunulmaktadır. Test sonuçları Tablo 5 'te yer almaktadır. 
Tablo 5. Levin-Lin-Chu birim kök testi

\begin{tabular}{lll}
\hline & Test İstatistiği & Olasıllk Değeri \\
\hline OZK & -1.75075 & $0.0400^{* *}$ \\
NO & -5.87504 & $0.0000^{*}$ \\
NIS & -4.01269 & $0.0000^{*}$ \\
KVBTB & -2.34115 & $0.0096^{*}$ \\
ISDH & -4.82407 & $0.0000^{*}$ \\
CO & -7.42268 & $0.0000^{*}$ \\
BO & -1.93583 & $0.0264^{* *}$ \\
AT & -2.74528 & $0.0030^{*}$ \\
ADH & -2.90463 & $0.0018^{*}$ \\
SDH & -1.98761 & $0.0234^{* *}$ \\
TBO & -1.51205 & $0.0653^{* * *}$ \\
SDH & -1.98761 & $0.0234^{* *}$ \\
\hline & ${ }^{*} 0,01,{ }^{* *} 0,05,{ }^{* * *} 0,10$ istatistiksel anlamll1k düzeyleridir.
\end{tabular}

Tablo 5'te yer alan birim kök testi sonuçları incelendiğinde tüm serilerde sıfır hipotezi reddedilememektedir. Levin-Lin-Chu birim kök testi sonuçları incelendiğinde, modeldeki tüm değişkenler, farklı istatistiksel anlamlılık seviyelerinde, düzey değerlerinde durağan olarak tespit edilmiştir. Panel veri analizi literatüründe sabit etkiler modeli (fixed effects) ve rassal etkiler modeli (random effects) olarak iki tahminci bulunmaktadır. Çalışmada hangi tahmincinin daha uygun olduğunun tespit edilmesi için Hausman testi uygulanmıştır (Hausman, 1978). Birim etkilerin bağımsız değişkenlerle korelasyonlu olup olmadığı, tahminci seçiminde incelenmesi gerekli olan bir noktadır. Hausman (1978) boş hipotez olarak, birim etkiler ile bağımsız değişkenler arasında korelasyon yoksa, tesadüfi etkiler modelinin daha etkin olacağını belirtmektedir. Bu durumda her iki tahminci de tutarlıdır ve iki tahminci arasındaki farkın çok küçük olması beklenmektedir. Testin alternatif hipotezi ise, bağımsız değişkenlerle birim (spesifik) etki arasında korelasyon olduğu şeklinde ifade edilmektedir. Bu durumda ise, rassal etkiler tahmincisi sapmalıdır ve tahminciler arasındaki farkın büyük olacağı beklenmektedir. Hausman test sonuçları Tablo $6^{\prime}$ te gösterilmiştir.

Tablo 6. Hausman test istatistiği

\begin{tabular}{lc}
\hline $\begin{array}{l}\chi^{2} \text { Değeri } \\
4.26\end{array}$ & Olasılık Değeri \\
\hline${ }^{*} 0,01,{ }^{* *} 0,05,{ }^{* * *} 0,10$ istatistiksel anlamlılık düzeyleridir.
\end{tabular}

Tablo 6 incelendiğinde, hata terimleri arasında ilişki olmadığı için sıfır hipotezi altında sabit etkiler tahmincisi tutarlı, rassal etkiler tahmincisinin ise etkin olduğu sonucuna ulaşılmıştır. $\mathrm{Bu}$ durumda, iki tahminciden birisi kullanılabilir. Panel veri analizi tahmini öncesinde yapılması gereken diğer bir sınama değişen varyansın test edilmesidir. Literatürde değişen varyans sorununu test eden birçok sınama bulunmaktadır. Çalışmada, Modified Wald Değişen Varyans testi tercih edilmiştir. Testin boş hipotezi, $\sqrt{H_{0}: \sigma_{i}^{2}=\sigma^{2}}$ şeklinde gösterilmektedir. Hipotez farklı birimler için hata terimlerinin varyanslarının tek bir varyans büyüklüğüne eşit olduğu anlamına gelmektedir. Hipotezin reddedilmesi değişen varyans probleminin varlığına işaret ederken; reddedilememesi durumu ise değişen varyans probleminin olmadığı şeklinde yorumlanmaktadır (Yerdelen Tatoğlu, 2016: 220). Test sonuçlarına Tablo 7'de yer verilmiştir. 
Tablo 7. Modified Wald değişen varyans test istatistikleri

\begin{tabular}{cc}
\hline$\chi 2$ Değeri & Olasılık Değeri \\
\hline 2724.33 & $0.0000^{*}$ \\
\hline${ }^{*} 0,01,{ }^{* *} 0,05,{ }^{* * *} 0,10$ istatistiksel anlamlılık düzeyleridir.
\end{tabular}

Tablo 7'de yer alan değişen varyans test istatistikleri incelendiğinde, modelde \%1 istatistiksel anlamlılık düzeyinde değişen varyans olduğuna karar verilmiştir. Analizlerde otokorelasyon sınaması yapmak amaciyla Wooldridge Otokorelasyon testi tercih edilmiştir. Wooldridge (2002)'in, panel veri modellerinde otokorelasyonu sınamak amacıyla geliştirdiği testin boş hipotezi, "birinci mertebeden otokorelasyon yoktur" şeklinde tanımlanmaktadır. Test, Eşitlik 5 'te yer alan birinci farklar modelinden elde edilen kalıntıları kullanmaktadır. Daha sonra, Eşitlik 6 'da yer alan regresyon tahmininden elde edilen kalıntıların, $\overline{e_{i}}$, gecikmeli değerleri ile regresyonu alınmaktadır.

$\left(Y_{i t}-Y_{i t-1}\right)=\left(X_{i t}-X_{i t-1}\right) \beta+\left(u_{i t}-u_{i t-1}\right)$

$\Delta Y_{i t}=\Delta X_{i t} \beta+\Delta u_{i t}$

$\Delta u_{i t}=e_{i t}$

Test istatistiğine Tablo 8 'te yer verilmiştir.

Tablo 8. Wooldridge otokorelasyon testi istatistiği

\begin{tabular}{cc}
\hline$\chi^{2}$ Değeri & Olasıllk Değeri \\
\hline 83.700 & $0.0000^{*}$ \\
${ }^{*} 0,01,{ }^{* *} 0,05,{ }^{* * *} 0,10$ istatistiksel anlamlllk düzeyleridir.
\end{tabular}

Tablo 8'de yer alan Wooldridge otokorelasyon test sonucu incelendiğinde, \%1 istatistiksel anlamlılık düzeyinde hata terimler arasında otokorelasyon olduğuna karar verilmiştir. Hata terimleri arasında hem değişen varyans hem de otokorelasyon bulunması nedeniyle panel veri tahminlerinin dirençli (robust) tahminci kullanılarak uygulanması gerekmektedir. Fakat doğru bir sonuç elde etmek amacıyla bağımsız değişkenler modele tek tek dahil edilerek tahminler tekrarlanmıştır. Ayrıca Tablo 3'te yer alan korelasyon matrisi de göz önünde bulundurulmuş ve çoklu doğrusal (multicollinearity) bağlılık problemi oluşturulmamaya çalışılmıştır. Tekrarlanan tahmin sonucunda anlamlı model Eşitlik 2'de, tahmin sonuçları ise Tablo 9'da gösterilmektedir.

$O Z K_{i t}=\beta_{1}+\beta_{2} C O_{i t}+\beta_{3} S D H_{i t}+\beta_{4} A K D H_{i t}+\beta_{5} T B O_{i t}+\beta_{6} N I S_{i t}+\varepsilon_{i t}$

Tablo 9. Panel veri analizi tahmin sonuçları

\begin{tabular}{llll}
\hline Değişkenler & Katsayılar & Std. Hata (Dirençli) & Olasıllk Değeri \\
\hline CO & -0.5672 & 0.0868 & $0.000^{*}$ \\
SDH & 0.0766 & 0.0060 & $0.000^{*}$ \\
AKDH & 0.0924 & 0.1745 & $0.000^{*}$ \\
TBO & -0.1074 & 0.0123 & $0.000^{*}$ \\
NIS & 0.4030 & 0.1734 & $0.020^{* *}$ \\
Sabit Terim & 15.8766 & 0.5931 & $0.000^{*}$ \\
\hline
\end{tabular}

${ }^{*} 0,01,{ }^{* *} 0,05,{ }^{* *} 0,10$ istatistiksel anlamlılık düzeyleridir.

Tablo 9'da, bağımlı değişken olarak kullanılan özsermaye karlılığı (ROE) ile bağımsız değişkenler arasındaki ilişki ortaya koyan panel veri analizi tahmin sonuçları yer almaktadır. Model tahmininde dirençli (robust) tahminci kullanılması sebebiyle tahminin $\mathrm{R}^{2}$ değeri 
hesaplanamamıştır. Ayrıca daha önce belirtildiği üzere Eşitlik 1'de yer alan tüm değişkenler modele teker teker dahil edilmiş ve anlamsız değişkenler modelden çıkarılarak Eşitlik 2 tahmin edilmiştir.

Tablo 9'da yer alan tahmin sonuçları incelendiğinde net işletme sermaye oranı hariç tüm değişkenlerin \%1 istatistiksel anlamlılık seviyesinde anlamlı olduğu, ilgili oranın ise \%5 seviyesinde anlamlı olduğu görülmektedir. Analiz sonuçlarına göre firmaların performans ölçütü olarak kullanılan özsermaye karlılığı, stok devir hızı, aktif devir hızı ve net işletme sermayesi oranından pozitif yönde etkilenirken; cari oran ve toplam borç oranından negatif yönde etkilenmektedir. Sonuçlar, finansal teori açısından beklenen düzeydedir. Analize dahil olan teknoloji firmalarının aktiflerinde yer alan likit seviyesini gereksiz arttırmaları karlılıklarını olumsuz etkilemektedir. Teknoloji firmaları açısından beklenen bir durum olan bu sonuç, firmaların elde ettikleri nakdi verimli kullanmaları gerektiğinin göstergesi olarak yorumlanabilir. Aynı şekilde, toplam borç oranını arttıran firmaların risk düzeylerinin yükseldiği ve karlılıklarının düştüğü tespit edilmiştir. Stok ve aktif devir hızı oranlarını arttıran firmaların, faaliyetlerini daha verimli gerçekleştirdiği ve sonuç olarak karlılıklarını artırabildikleri ise bir diğer bulgudur. Çalışmanın temel amacı doğrultusunda modelde yer alan net işletme sermayesi oranı incelendiğinde, teknoloji firmalarının net işletme sermayesi yönetiminin önemi dikkat çekmektedir. Bir birimlik satış karşılığında bulundurulması gereken net işletme sermayesini ifade eden oran, özsermaye karlılı̆̆ı üzerinde pozitif etkilidir ve en yüksek katsayıya sahiptir. Dolayısıyla net işletme sermayesi yönetimine odaklanan teknoloji firmalarının karlılıklarını ciddi oranda yükseltebileceği kınasına ulaşılmıştır.

\section{SONUÇ}

İşletme sermayesi, bilanço aktifinde yer alan ve kısa bir sürede paraya dönüşebilen varlıklardan oluşmaktadır. İşletme sermayesi yönetimi tüm firmalar açısından karlılık çerçevesinde önemlidir. Ancak, teknoloji firmaları açısından işletme sermayesi yönetimi, hızlı değişen pazar şartları ve şiddetli rekabet nedeniyle daha da önemli görülmektedir. Tüm firmalar için olduğu kadar teknoloji firmaları için de işletme sermayesi yönetimi için iki temel sorun bulunmaktadır. Birincisi teknoloji firmalarının işletme sermayesi tutarının hangi dönemlerde hangi seviyede olması gerektiğinin tespitidir. İkincisi önemli sorun ise işletme sermayesinin hangi kaynaklarla ve nasıl finans edileceğidir. Bu iki soruna çözüm bulabilmiş firmalar, karlılıklarını optimize etme fırsatı elde edebilmektedir.

Bu çalışmanın amacı, Borsa İstanbul'da 2015-2020 yılları arasında kesintisiz faaliyet gösteren 13 teknoloji firmasının, işletme sermayesi yönetiminin karlılıklarına etkisini araştırmaktır. Araştırma kapsamında firmalara ait çeyreklik finansal tablolar kullanılarak derlenerek toplam 312 gözlemden yararlanmıştır. Çalışmada gerekli sınamalar yapıldıktan sonra panel veri analizi için dirençli (robust) tahminci kullanılmıştır.

Elde edilen ilk bulgularda, 11 açıklayıcı değişkenden sadece beş tanesinin bağımlı değişken olan özsermaye karlılığı üzerinde istatistiksel olarak anlamlı etkisi olduğu gözlenmiştir. Bu finansal oranlardan stok devir hızı, aktif devir hızı ve net işletme sermayesinin etkisinin pozitif yönde; cari oran ve kaldıraç oranının ise negatif yönde olduğu tespit edilmiştir. Bulgular literatürde yer alan çalışmalarla tutarlıdır. 
Sonuçlar detaylı şekilde incelendiğinde, teknoloji sektöründe faaliyet gösteren firmaların, cari oranlarında bir artış meydana gelmesi karlılıkta bir düşüşe yol açarken; net işletme sermayesi oranındaki bir artış aksi etki göstermektedir. Firmalar gereksiz dönen varlık bulundurmaları durumunda verimsiz hale gelmektedir. Diğer yandan, bir birim satış başına net işletme sermayesi tutarını arttırırlarsa verimlilikleri pozitif yönde etkilenmektedir. Kaldıraç oranının, karlılık üzerindeki negatif etkisi ise teorik olarak beklenen bir durumdur. Teknoloji firmalarının borç seviyelerinin artması risk algısını güçlendirmekte ve özsermaye karlılığını olumsuz etkilemektedir. Faaliyet oranları olarak modelde yer alan stok devir hızı ve aktif devir hızının artması, firmanın faaliyetlerinin güçlenmesi olarak yorumlanabilmektedir. Bu oranların özsermaye karlılığı üzerindeki olumlu etkisi de teorik beklentilere uygundur.

Sonuç olarak işletme sermayesi yönetiminin teknoloji firmaları için ciddi öneme sahip olduğu gözlenmiştir. İşletme sermayesi ile ilgili finansal kararların etkin bir şekilde yönetilmesi hem firma karlılığının optimize edecek hem de firma risk alg1sı üzerine katkı sağlayabilecektir.

\section{KAYNAKÇA}

Akbulut, R. (2011). İMKB'de İmalat Sektöründeki İşletmelerde İşletme Sermayesi Yönetiminin Karlılık Üzerindeki Etkisini Ölçmeye Yönelik Bir Araştırma. İstanbul Üniversitesi İşletme Fakültesi Dergisi, 40(2), 195-206.

Akgüç, Ö. (1982) Finansal Yönetim, İstanbul. 3. Baskı.

Altan, M. ve Şekeroğlu, G. (2013). Çalışma Sermayesi Finanslama Stratejilerinin Firma Karlılığı Üzerine Etkileri: İMKB'de Kayıtlı Firmalar Üzerinde Bir Araştırma. Selçuk Üniversitesi Sosyal Bilimler Enstitüsü Dergisi, 30, 223-228.

Arshad, Z. \& Yasir, M. G. (2013). Impact Of Working Capital Management On Profitability A Case Of The Pakistan Cement Industry. Interdisciplinary Journal Of Contemporary Research In Business, 5(2), 384-390.

Aydın, N., Şen, M. ve Berk, N. (2014). Finansal Yönetim-1. 3. Baskı. Eskişehir: Anadolu Üniversitesi Yayıncılık.

Aygün M. (2012). Firma Performansı Üzerinde Çalışma Sermayesinin Etkisi: Türk İmalat Sektörü Üzerine Bir Uygulama. Ege Akademik Bakış, 12(2), 215-223.

Breusch, T. S. \& Pagan, A. R. (1980). The Lagrange Multiplier Test and İts Applications to Model Specification in Econometrics. The Review of Economic Studies, 47(1), 239-253.

Brigham E. F \& Ehrhardt. M. C. (2019) Financial Management Theory And Practice 13th edition.

Charitou, M. Petros, C. L. \& Budi, H. S. (2012). The Relationship Between Working Capital Management And Firm's Profitability: An Empirical Investigation For An Emerging Asian Country. International Business E Economics Research Journal, 11(8): 839-848.

Coşkun, E. ve Kök, D. (2011). Çalışma Sermayesi Politikalarının Karlılık Üzerine Etkisi: Dinamik Panel Uygulaması. Ege Akademik Bakış, 11(2011), 75-85. 
Çankaya, M. (2020). Sağlık Sektörü İşletmelerinde İşletme Sermayesi Yönetiminin Karlılık Üzerindeki Etkisi: Borsa İstanbul (BİST) Örneği. Aksaray Üniversitesi İktisadi ve İdari Bilimler Fakültesi Dergisi, 12(4), 1-14.

Dinçergök, B. (2019). İşletme Sermayesi Yönetimi ve Karlılık İlişkisi: Doğrusal Olmayan İlişkinin BIST Kimya, Petrol, Kauçuk Ve Plastik Ürünler Sektöründe Sınanması. Muhasebe ve Finansman Dergisi, 82, 161- 176.

Eskin, İ. ve Güvemli, B. (2019). Çalışma Sermayesi Yönetiminin Kârlılı̆̆a Etkisi: Borsa İstanbul 50 Endeksi Örneği. Muhasebe ve Finansman Dergisi, (85), 65-76.

Hausman, J. (1978). Specification Tests in Econometrics. Econometrica, 46(6), 1251-1271.

Helhel, Y. ve Karasakal, S. (2017). Konaklama İşletmelerinde Çalışma Sermayesi Yönetiminin Karlılık Performansina Etkisi: Borsa İstanbul'da (BİST) Bir Uygulama. Seyahat ve Otel İşletmeciliği Dergisi 14 (3), 27-39.

Karaduman, H. A. Akbas, H. E. Ozsozgun, A. \& Durer, S. (2010). Effects Of Workıng Capital Management On Profitability: The Case For Selected Companies In The Istanbul Stock Exchange (2005- 2008). International Journal Of Economics And Finance Studies, 2(2), 47-54.

Karagözoğlu, G. Aktaş, R. ve Kayalıdere, K. (2019). Çalışma Sermayesi ile Finansal Performans Arasındaki İlişkinin Alt Sektörler Bazında Karşılaştırmalı İncelenmesi: BIST Örneği. Muhasebe Bilim Dünyası Dergisi, 21 (3), 628-654.

Kaynar, B. B. (2018). Çalışma Sermayesi Yönetiminin İşletme Performansı Üzerine Etkisi: Lojistik Sektörüne Yönelik Panel Veri Analizi. Internatıonal Caucasus-Central Asıa Foreign Trade And Logistics Congress, 715-725.

Kendirli, S. ve Konak, F. (2014). İşletme (Çalışma) Sermayesi Yönetiminin Firma Performansı Üzerindeki Etkisi: Bist Gıda, İçecek Endeksi Uygulaması. Akademik Bakış Dergisi, 41.

Korkmaz T. ve Yaman S. (2019). Çalışma sermayesi yönetiminin firma karlılığına etkisi: BIST turizm firmaları üzerine bir uygulama. Journal of Tourism Theory and Research, 5(2), 301-316.

Lazaridis, İ. \& Tryfonidis, D. (2006). Relatıonshıp Between Workıng Capıtal Management And Profitability Of Listed Compnies In The Athens Stock Exchange. Journal Of Financial Management $\mathcal{E}$ Analysis, 19(1), 26-35.

Levin, A. Lin, C. F. \& Chu, C. S. J. (2002). Unit Root Tests in Panel Data: Asymptotic and FiniteSample Properties. Journal of Econometrics, 108(1), 1-24.

Mbawuni, J. Hawa, M. M. \& Gyasi, S. N. (2016). The Impact Of Working Capital Management On Profitability Of Petroleum Retail Firms: Empirical Evidence From Ghana. International Journal Of Economics And Finance, 8(6), 49-62.

Nazir, M. S. \& Afza, T. (2009). Impact Of Aggressive Working Capital Management Policy On Firms' Profitability, The IUP Journal Of Applied Finance, 15(8), 20-30. 
Nur, Ö. Ç. ve Gökhan, A.S. (2019). Çalışma Sermayesi Yönetiminin Firma Karlılığ1 Üzerindeki Etkisi: BİST'te İşlem Gören Metal Eşya, Makine Ve Gereç Yapım Sektörü Üzerinde Bir Araştırma. A ̈̆ Üniversitesi Sosyal Bilimler Dergisi, 16(2), 35-42.

Öner, M. (2016). The Impact Of Working Capital Management On Firm Profitability: Empirical Evidence From Bursa Istanbul. Research Journal Of Politics, Economics And Management, 4(3), 63-79.

Raheman, A. \& Mohamed, N. (2007). Working Capital Management And Profitability - Case Of Pakistani Firms. International Review Of Business Research Papers, 3(1), 279 - 300.

Ponsian, N. (2014). The Effect Of Working Capital Management On Profitability. International Journal Of Economics, Finance And Management Sciences 2(6), 347-355.

Türkmen, S. Y. ve Söylemez, Y. (2019). İşletme Sermayesi Unsurlarının Firma Karlılığ1 Üzerindeki Etkisi: Demir, Çelik ve Ana Metal Sanayi Sektörü Örneği. Maliye ve Finans Yazıları, 11,11-32.

Uyar, U. ve Sarak, G. (2020). Finansal Oranlar ile Firma Değeri İlişkisinin Borsa İstanbul ve Londra Borsası İmalat Sanayi Sektörlerinde Karşılaştırılması. Ekonomi, Politika $\mathcal{E}$ Finans Araştırmaları Dergisi, 5(3), 537-560.

Vural, G. Gökhan, A. S. Hüseyin E. Ç. (2012). Affects Of Working Capital Management On Firm's Performance: Evidence From Turkey. International Journal Of Economics And Financial, 2(4), 488-495.

Yerdelen Tatoğlu, F. (2016). Panel Veri Ekonometrisi - Stata Uygulamal. Beta Yayınları, İstanbul.

Yenisu, E. (2019). İşletme Sermayesi Yönetiminin Firma Karlılığına Etkisi: Bıst Bursa İşletmeleri Örneği. Bankacılık ve Finansal Araştırmalar Dergisi (Bafad), 6(2), 53-64.

Wooldridge, J. M. (2002). Econometric Analysis of Cross Section and Panel Data. Cambridge, Ma: MIT Press.

Zengin, N. Şenol, Z. ve Yıldız, Z. (2017). Firma Karlılığının İşletme Sermayesi Üzerine Etkisi: BİST Uygulaması (2005-2015). Paradoks Ekonomi, Sosyoloji ve Politika Dergisi, 13(2), 114. 